\title{
Producing and Marketing Strawberries for Direct Market Operations
}

\author{
Charles D. Safley, \\ E. Barclay Poling, ${ }^{2}$ \\ Michael K. Wohlgenant, ${ }^{3}$ \\ Olga Sydorovych, ${ }^{4}$ and \\ Ross F. Williams ${ }^{5}$
}

\begin{abstract}
AdDitional INDEX WORDS. cost of production, breakeven analysis, consumer demographics, direct marketing, advertising, Fragaria $\times$ ananassa

Summary. The costs associated with growing, harvesting and marketing strawberries (Fragaria $\times$ ananassa) using the plasticulture production system were estimated to be $\$ 13,540 /$ acre $(\$ 33,457 /$ ha $)$. Net revenue analysis showed that growers would have to charge at least $\$ \mathbf{0 . 8 5}$ and $\$ 1.40 / 1 b(\$ 1.87$ to $\$ 3.09 / \mathrm{kg})$ for pick-your-own (PYO) and prepicked fruit, respectively, and sell 12,000 lb of berries per acre $(13,449.9$ $\left.\mathrm{kg} \cdot \mathrm{ha}^{-1}\right)$ to cover this expense. Breakeven analysis indicated that growers would have to charge a PYO price of $\$ 0.65 / 1 \mathrm{~b}(\$ 1.43 / \mathrm{kg})$ and $\$ 1.20 / \mathrm{lb}$ $(\$ 2.64 / \mathrm{kg})$ for prepick berries and sell a minimum of $15,041 \mathrm{lb} /$ acre $\left(16,858.4 \mathrm{~kg} \cdot \mathrm{ha}^{-1}\right)$ to cover the projected expenses. However, if a grower received $\$ 0.95$ and $\$ 1.50 / 1 b(\$ 2.09$ and $\$ 3.31 / \mathrm{kg}$ ) for the PYO and prepicked fruit, respectively, he/she would only have to sell $10,622 \mathrm{lb}$ of berries per acre $\left(11,905.4 \mathrm{~kg} \cdot \mathrm{ha}^{-1}\right)$ to break even. It was assumed that an average of $11.6 \mathrm{lb}(5.26 \mathrm{~kg})$ of fruit
\end{abstract}

${ }^{1}$ Professor, Department of Agricultural and Resource Economics, North Carolina State University, Raleigh, NC 27695-8109.

${ }^{2}$ Professor, Department of Horticultural Science, North Carolina State University, Raleigh NC 27695-7609.

${ }^{3}$ William Neal Reynolds distinguished professor, Department of Agriculture and Resource Economics, North Carolina State University, Raleigh, NC 27695-8109

${ }^{4}$ Graduate research assistant, Department of Agricultural and Resource Economics, North Carolina State University, Raleigh, NC 27695-8109.

${ }^{5}$ Assistant director for horticultural crops and field crop marketing, Division of Markets, North Carolina Department of Agriculture and Consumer Services, Raleigh NC 27611. 
would be sold to PYO customers and an average of $7.1 \mathrm{lb}(3.22 \mathrm{~kg})$ would be sold to customers who visited the fruit stand. Under these assumptions, the breakeven yield of $14,724 \mathrm{lb} /$ acre translates into a requirement to sell fruit to at least 1,539 customers per acre $(3,802.8$ customers $/$ ha $)$ at the lowest combination of prices while a yield of $10,398 \mathrm{lb} /$ acre converts to a minimum of 1,087 customers per acre $(2,685.9$ customers / ha $)$ at the higher prices. Customers were also surveyed at direct market operations in Spring 1999 to gain insight into consumer demographic characteristics, why customers select a specific PYO or prepick direct market strawberry outlet, average expenditures per customer, typical driving distances to direct market strawberry operations, and the effectiveness of advertising. Middle age, middle-income customers living within 10 miles $(16.1 \mathrm{~km})$ of the farm comprised the largest percentage of customers surveyed at the PYO operations, while middle age, high-income individuals who also live within 10 miles of the fruit stand were the largest group of respondents at the fruit stands. PYO customers spent an average of $\$ 10.30$, and prepick consumers spent an average of $\$ 9.40$ per visit. Less than $23 \%$ of all the respondents said that advertising influenced their shopping decision while $>77 \%$ indicated that any type of advertisement did not influence their decision. Overall, convenient location was easily the major reason that customers decided to patronize a specific direct market outlet while personal referrals were second.

C urrent and potential strawberry growers need production, marketing, and financial information to make informed decisions about entering, leaving, or expanding existing operations. Like all business owners their main objective should be to make a profit in order for their farms to be financially successful. Ideally, growers would keep detailed records that would serve as a reference when estimating their production, harvest, and marketing costs, but this typically does not happen. Marketing is also a key factor in the success of horticultural enterprises that sell produce directly to the final consumers. Direct marketers who can target their potential customers, know why consumers buy their products and can attract customers to their operations are better prepared to provide the goods and services necessary to be successful. However few direct market growers have the resources necessary to conduct extensive consumer surveys to discover information that will help improve their marketing efforts.

Therefore, this report has two overall purposes. The first is to provide information about the costs and returns of growing, harvesting and marketing strawberries at direct market operations. The second is to identify direct market strawberry customers and present information about their buying behavior. Specific objectives of this report are as follows:

1. Estimate the costs associated with growing, harvesting and marketing strawberries for a typical direct market operation using the strawberry plasticulture production system.

2. Evaluate the effects of varying prices and yields.

3. Identify and characterize direct market strawberry customers.

4. Identify the key factors that influence consumer purchase decisions.

5. Discuss the effectiveness of advertising on influencing consumers to visit direct market strawberry operations.

\section{Materials and methods}

To accomplish the budgeting objectives, a complete cost model for a plasticulture production system was developed for a 5 -acre (2.0-ha) strawberry planting (Safley et al., 2003) Production practices were based on above average management practices recommended by North Carolina State University extension and research horticultural specialists, tempered with real world practices.

It was assumed that all the machinery and equipment were purchased new at 2001 purchase prices. The machinery and equipment used in this budget reflects machinery components that can be used for other farming enterprises in addition to growing strawberries on a typical diversified farm. Therefore the machinery expenses reflect the equipment costs for a total farm business and not just for strawberry production. The exceptions to this are the fumigation and irrigation equipment, which was used solely for strawberry production. The overhead irrigation system was a hand-moved sprinkler system used primarily for frost and freeze protection and the drip irrigation system was used for soil moisture.

Input prices were obtained from local dealers who regularly supply North Carolina strawberry growers. Because land values vary throughout the state, a land charge was not included in this budget however growers should include a land charge that is representative of current land values in their region. Hired employees were paid $\$ 8.25 / \mathrm{h}$ while the owner/operator was compensated at a rate of $\$ 16.39 /$ h. These labor rates include workers' compensation, unemployment, FICA taxes and other overhead expenses as well as the base wage rate and were meant to be representative of the true costs of labor and not just the base wage rate.

The harvest season was assumed to last 6 weeks starting in the third week of April and continuing through May. The marketing process obviously bears a cost and this cost will vary considerably depending on the marketing system producers decide to use. In this study it was assumed that all of the fruit would be sold at the farm with two-thirds of the strawberries sold through the PYO operation and onethird sold at the fruit stand. A labor charge of $\$ 1.15 / 4$-qt $(3.8-\mathrm{L})$ basket was added to the cost of the prepick strawberries; while supervision labor was compensated at a rate of $\$ 8.25 / \mathrm{h}$. Supervision tasks included overseeing the pickers and checkout operations as well as the general management of the direct market operations.

The customer survey was conducted at eight direct market strawberry operations throughout the state during Spring 1999 (Safley et al., 2002). These operations represented typical strawberry operations across North Carolina in the major production areas from the coastal to the mountain regions. Since normal harvest dates vary by region, the surveys were completed in April in the coastal area, May in the Piedmont region, and June in the Mountain region. Enumerators visited each location for 6 continuous days, Monday through Saturday, to interview the customers. Each operation offered the customers two options for buying strawberries. They could either pick their own strawberries from the grower's field or they could buy prepicked strawberries at the grower's fruit stand.

The survey was divided into two segments. The first segment was administered when the customer arrived at the direct market operation. This part focused on their previous experi- 
ence of picking strawberries, if they planned to pick their own fruit or buy prepicked fruit, and the effect advertising had on their decision to visit the operation where they were interviewed. The second part was conducted as the customers left the operation and concentrated on their actual purchases, how the berries were to be used, the quality of the fruit and services received at the strawberry operation, and the socioeconomic characteristics needed to identify the various market segments. Although some respondents did not answer every question, a total of 1,665 usable questionnaires were collected.

\section{Results}

The total harvest, marketing, and production costs using the plasticulture production system were estimated to be $\$ 13,540 /$ acre (Table 1). Expenses were separated into six production phases: 1) land preparation, 2) preplant operations, 3) transplant and postplant operations, 4) dormant phase, 5) preharvest, and 6) harvest operations. Preplant operations were the most expensive procedures costing an estimated $\$ 4,399 /$ acre $(\$ 10,869 /$ ha $)$, or $32.5 \%$ of the total costs, while harvest operations were the second most expensive phase costing $\$ 3,262$ /acre $(\$ 8,060 /$ ha $)$, or $24.1 \%$ of the total. Preharvest operations accounted for $17.5 \%$ of the total costs at $\$ 2,369 /$ acre $(\$ 5,854 / \mathrm{ha})$ and transplant and postplant operations comprised $14.9 \%$ of the total at $\$ 2,015 /$ acre $(\$ 4,979 /$ ha). Overall materials accounted for $49.8 \%$, or $\$ 6,750 /$ acre $(\$ 16,579 /$ ha $)$, of the total estimated expenses, labor costs made up slightly over $38 \%$, or $\$ 5,180 /$ acre $(\$ 12,800 /$ ha $)$, and the

Table 1. Estimated costs per acre needed to produce, harvest and market strawberries (Fragaria $\times$ ananassa) at a direct-market operation in North Carolina using the plasticulture production system.

\begin{tabular}{|c|c|c|c|c|}
\hline Operation & $\begin{array}{c}\text { Labor } \\
(\$ / \text { acre })^{z}\end{array}$ & $\begin{array}{c}\text { Machinery } \\
\text { (\$/acre) }\end{array}$ & $\begin{array}{c}\text { Materials } \\
\text { (\$/acre) }\end{array}$ & $\begin{array}{c}\text { Total } \\
\text { (\$/acre) }\end{array}$ \\
\hline \multicolumn{5}{|l|}{ Land preparations } \\
\hline Treat old crop with paraquat & 14.85 & 20.52 & 7.38 & 42.75 \\
\hline Remove and dispose plastic & 158.40 & 68.80 & 0.00 & 227.20 \\
\hline Disking & 2.52 & 5.86 & 0.00 & 8.38 \\
\hline Liming & 0.00 & 0.00 & 26.00 & 26.00 \\
\hline Planting soybeans ${ }^{y}$ for cover crop & 24.75 & 89.13 & 39.33 & 153.21 \\
\hline Total land preparation costs $(\$)$ & 200.52 & 184.31 & 72.71 & 457.54 \\
\hline \multicolumn{5}{|l|}{ Preplant operations } \\
\hline Ordering plant material, fumigant, plastic mulch ( $10 \%$ deposit) & 5.74 & 0.00 & 219.80 & 225.54 \\
\hline Rotovating cover crop & 56.04 & 118.02 & 0.00 & 174.06 \\
\hline Pull greenhouse shadecloth & 4.95 & 0.00 & 187.74 & 192.69 \\
\hline Set-up misting system & 9.48 & 0.00 & 0.00 & 9.48 \\
\hline Plug supplies (tips, trays, soil) & 2.06 & 0.00 & $1,884.44$ & $1,886.50$ \\
\hline Stick runner tips for plugs & 315.81 & 0.00 & 0.00 & 315.81 \\
\hline Handling trays & 33.01 & 0.00 & 0.00 & 33.01 \\
\hline Subsoiling & 14.85 & 8.15 & 0.00 & 23.00 \\
\hline Disking (break up soil clods) & 2.52 & 5.86 & 0.00 & 8.38 \\
\hline Moisten soil media & 8.25 & 0.00 & 0.00 & 8.25 \\
\hline $\mathrm{OH}^{\mathrm{x}}$ irrigate and fertilize plugs $(20 \mathrm{~N}-8.8 \mathrm{P}-16.6 \mathrm{~K})$ & 8.25 & 0.84 & 0.72 & 9.81 \\
\hline Spray for two-spotted spider mites ${ }^{y}$ with hexakis & 8.25 & 0.17 & 28.00 & 36.42 \\
\hline Assembling irrigation system & 99.00 & 2.04 & 0.00 & 101.04 \\
\hline Irrigating for fumigation & 0.83 & 7.61 & 0.00 & 8.44 \\
\hline Rotovating for fumigation & 28.03 & 59.01 & 0.00 & 87.04 \\
\hline $\begin{array}{l}\text { Preplant fertilization (ammonium nitrate, potassium sulfate, triple } \\
\text { super phosphate) }\end{array}$ & 7.43 & 10.42 & 48.46 & 66.31 \\
\hline Preplant fumigation (methyl bromide+chloropicrin) $(67 \%+33 \%)$ & 39.34 & 288.06 & 873.70 & $1,201.10$ \\
\hline Seed annual ryegrass ${ }^{y}$ in aisles & 0.84 & 0.63 & 11.00 & 12.47 \\
\hline Total preplant costs $(\$)$ & 644.68 & 500.81 & $3,253.86$ & $4,399.35$ \\
\hline \multicolumn{5}{|l|}{ Transplant and postplant } \\
\hline Transplant plugs and replant & 255.75 & 39.18 & 0.00 & 294.93 \\
\hline Irrigating plug establishment (three applications) & 101.48 & 169.53 & 0.00 & 271.01 \\
\hline Drip irrigation (three 2 -h applications) & 4.95 & 30.96 & 0.00 & 35.91 \\
\hline Spray for two-spotted spider mites with bifenthrin & 4.58 & 6.92 & 248.00 & 259.50 \\
\hline Collect tissue sample & 2.06 & 0.00 & 4.00 & 6.06 \\
\hline Winterize drip system & 16.50 & 0.00 & 0.00 & 16.50 \\
\hline Apply floating row covers & 50.48 & 2.04 & $1,079.00$ & $1,131.52$ \\
\hline Total transplant and postplant costs $(\$)$ & 435.80 & 248.63 & $1,331.00$ & $2,015.43$ \\
\hline \multicolumn{5}{|l|}{ Dormant period } \\
\hline Internet and weather service (annual fee, \$) & 0.00 & 0.00 & 83.88 & 83.88 \\
\hline Remove and reapply row covers & 297.00 & 0.00 & 0.00 & 297.00 \\
\hline White-tail deer ${ }^{y}$ control & 24.75 & 0.00 & 96.25 & 121.00 \\
\hline Ordering containers, fertilizers, etc. & 12.30 & 0.00 & 0.00 & 12.30 \\
\hline Remove row cover, dead foliage, mow leaves & 478.50 & 6.30 & 0.00 & 484.80 \\
\hline Dormant spray (captan) & 2.29 & 3.46 & 14.00 & 19.75 \\
\hline Scout for two-spotted spider mites & 16.39 & 0.00 & 0.00 & 16.39 \\
\hline Total dormant costs $(\$)$ & 831.23 & 9.76 & 194.13 & $1,035.12$ \\
\hline
\end{tabular}


costs linked to owning and operating the equipment comprised almost $12 \%$, or $\$ 1,611 /$ acre $(\$ 3,981 / \mathrm{ha})$.

MoNTHLY EXPENSES. The estimated monthly expenses for the major cost categories give growers an idea of their potential cash flow obligations (Table 2). Production costs in August and September totaled $\$ 4,761 /$ acre $(\$ 11,764 / \mathrm{ha})$, or $35.2 \%$ of the total expenses, and the operations in April and May cost $\$ 3,683 /$ acre $(\$ 9,100$ / ha), or $27.2 \%$ of the total. Preplant, transplant, and postplant operations comprised most of the expenses in August and September while the harvest operations made up the ma- jority of the costs in April and May. March expenditures were \$1,473/acre $(\$ 3,640 / \mathrm{ha})$, or almost $11 \%$ of the total costs, and November expenses totaled $\$ 1,266 /$ acre $(\$ 3,128 /$ ha $)$, which was slightly $>9 \%$ of the total.

Net Revenue. Net revenue will depend on the marketable yield and the price growers receive for their strawberries. As in most farming operations, growers can have a tremendous influence on their crop yields. The better job they do in caring for the crop, the more likely they will have higher yields of high quality fruit. However, the local markets will determine the maximum price for which growers can sell their berries. The consumer survey revealed that there was significant variation in the prices the eight cooperating growers charged for their PYO and prepicked strawberries. PYO prices ranged from $\$ 0.70$ to $\$ 1.05 / \mathrm{lb}$ ( $\$ 1.54$ to $\$ 2.31$ / $\mathrm{kg})$ and averaged $\$ 0.88 / \mathrm{lb}(\$ 1.94 /$ $\mathrm{kg}$ ) for the eight operations while prepicked prices ranged from $\$ 0.90$ to $\$ 1.7 \mathrm{l} / \mathrm{lb}(\$ 1.98$ to $\$ 3.77 / \mathrm{kg})$ and averaged $\$ 1.38 / \mathrm{lb}(\$ 3.04 / \mathrm{kg}$ ) (Table $3)$. The smallest price gap between the two types of direct market outlets was $\$ 0.20 / \mathrm{lb}(\$ 0.44 / \mathrm{kg})$ at Location I where the owner charged $\$ 0.70 / \mathrm{lb}$ for PYO berries and $\$ 0.90 / \mathrm{lb}$ for prepicked fruit. Conversely, the largest

Table 1 (continued). Estimated costs per acre needed to produce, harvest and market strawberries (Fragaria $\times a n a n a s s a)$ at a direct-market operation in North Carolina using the plasticulture production system.

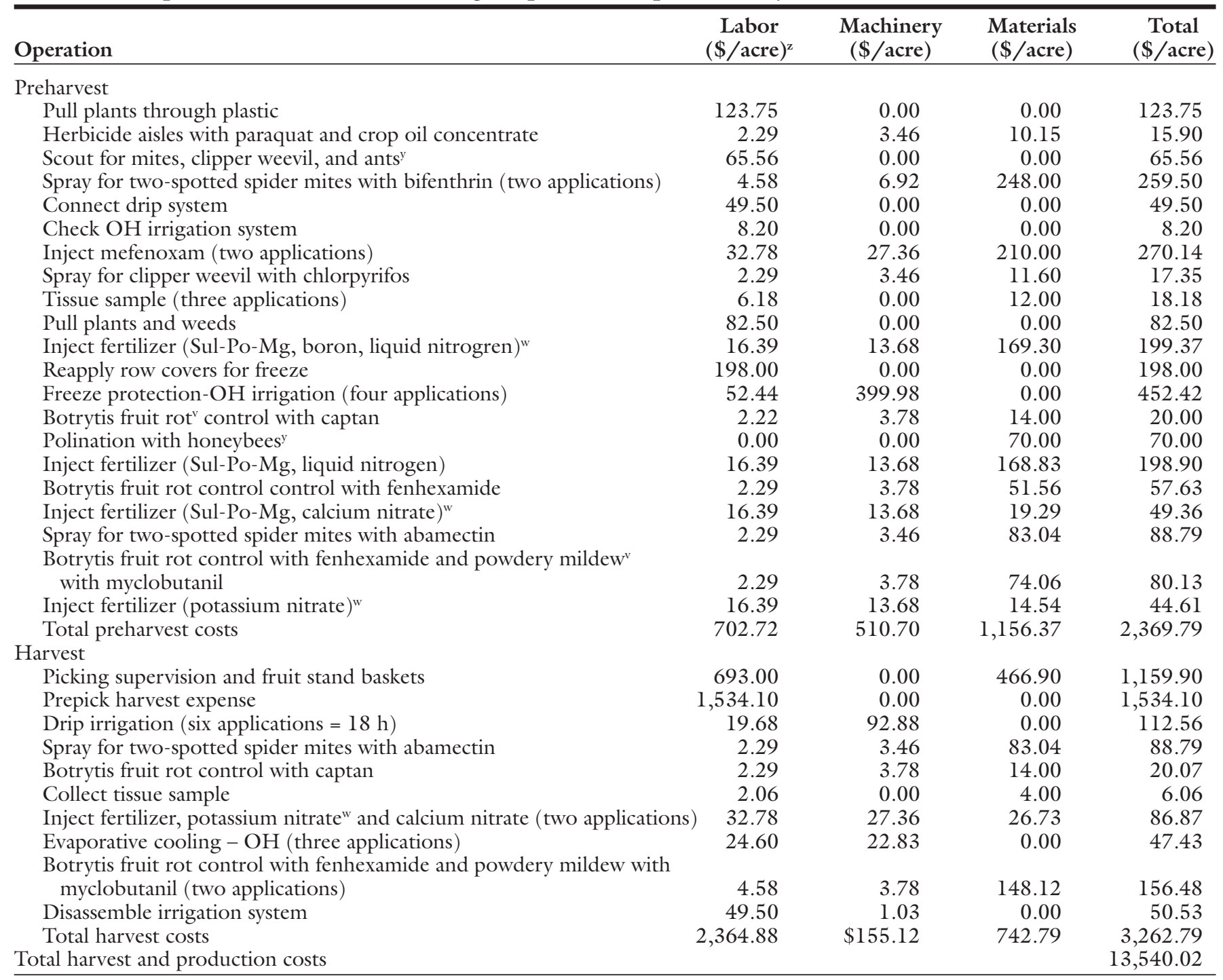

${ }^{\mathrm{z}} \$ 1 /$ acre $=\$ 2.47 / \mathrm{ha}, \mathrm{l}$ acre $=0.405$ ha.

ySoybean (Glycine max), two-spotted spider mite (Tetranychus urticae), annual ryegrass (Lolium perenne), white-tail deer (Odocoileus virginianus), strawberry clipper weevil (Anthonomus signatus), red fire ant (Solenopsis wagneri), honeybee (Apis mellifera).

${ }^{\mathrm{x}} \mathrm{OH}=$ overhead

${ }^{\mathrm{w}} \mathrm{Ammonium}$ nitrate $=34 \mathrm{~N}-0 \mathrm{P}-0 \mathrm{~K}$, potassium sulfate $=0 \mathrm{~N}-0 \mathrm{P}-36.5 \mathrm{~K}-1 \mathrm{Mg}-18 \mathrm{~S}$, triple super phosphate $=0 \mathrm{~N}-22 \mathrm{P}-0 \mathrm{~K}-12 \mathrm{Ca}-1 \mathrm{~S}, \mathrm{Sul}-\mathrm{Po}-\mathrm{Mg}=0 \mathrm{~N}-0 \mathrm{P}-17.8 \mathrm{~K}-10.5 \mathrm{Mg}-21 \mathrm{~S}$, boron $=0 \mathrm{~N}-0 \mathrm{P}-0 \mathrm{~K}-20 \mathrm{~B}$, liquid nitrogen $=30 \mathrm{~N}-0 \mathrm{P}-0 \mathrm{~K}$, calcium nitrate $=15 \mathrm{~N}-0 \mathrm{P}-0 \mathrm{~K}-19 \mathrm{Ca}-1 \mathrm{Mg}$, potassium nitrate $=13 \mathrm{~N}-0 \mathrm{P}-35.5 \mathrm{~K}$.

${ }^{\vee}$ Causal organisms of botrytis fruit rot and powdery mildew are Botrytis cinerea and Sphaerotheca macularis, respectively. 
Table 2. Estimated monthly equipment, material and labor costs per acre needed to produce, harvest, and market strawberries at a direct-market operation in North Carolina using the plasticulture production system.

\begin{tabular}{lcccr}
$\begin{array}{l}\text { Year } \\
\text { and } \\
\text { month }\end{array}$ & $\begin{array}{c}\text { Equipment } \\
\text { costs } \\
(\$ / \text { acre })^{\mathrm{z}}\end{array}$ & $\begin{array}{c}\text { Materials } \\
\text { costs } \\
(\$ / \text { acre })\end{array}$ & $\begin{array}{c}\text { Labor } \\
\text { costs } \\
(\$ / \text { acre })\end{array}$ & $\begin{array}{c}\text { Total } \\
\text { monthly } \\
\text { costs } \\
(\$ / \text { acre })\end{array}$ \\
\hline $\begin{array}{l}\text { First year } \\
\text { June }\end{array}$ & 184 & 78 & 200 & 462 \\
$\quad$ July & 0 & 225 & 6 & 231 \\
August & 132 & 2,077 & 435 & 2,664 \\
September & 577 & 967 & 553 & 2,097 \\
October & 34 & 132 & 34 & 200 \\
November & 5 & 1,208 & 53 & 1,266 \\
December & 0 & 5 & 297 & 302 \\
Second year & & & & 643 \\
$\quad$ January & 10 & 115 & 518 & 540 \\
February & 24 & 262 & 254 & 1,473 \\
March & 345 & 722 & 406 & 1,181 \\
April & 159 & 405 & 617 & 2,502 \\
$\quad$ May & 141 & 554 & 1,807 & 13,541 \\
Total cost & 1,611 & 6,750 & 5,180 & \\
Total cost $(\%)$ & 11.9 & 49.8 & 38.3 & \\
\hline
\end{tabular}

${ }^{{ }} \$ 1 /$ acre $=\$ 2.47 /$ ha

price gap was $\$ 0.79 / \mathrm{lb}(\$ 1.74 / \mathrm{kg})$ at Location 8 where the PYO strawberry price was $\$ 0.92 / \mathrm{lb}(\$ 2.03 / \mathrm{kg})$ and the

Table 3. The prices charged for pickyour-own and prepick strawberries at eight North Carolina direct-market operations that participated in a consumer survey during the 1999 strawberry season.

\begin{tabular}{lcc}
\hline Location & $\begin{array}{c}\text { Pick-your-own } \\
\text { price } \\
(\$ / \mathbf{l b})^{\mathrm{z}}\end{array}$ & $\begin{array}{c}\text { Prepick } \\
\text { price } \\
(\$ / \mathbf{l b})\end{array}$ \\
\hline 1 & 0.70 & 0.90 \\
2 & 1.05 & 1.33 \\
3 & 0.85 & 1.25 \\
4 & 1.00 & 1.40 \\
5 & 0.80 & 1.25 \\
6 & 0.85 & 1.50 \\
7 & 0.90 & 1.67 \\
8 & 0.92 & 1.71 \\
Average & 0.88 & 1.38 \\
\hline $2 \$ 100 / 1 b$
\end{tabular}

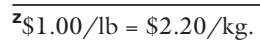

prepicked price was $\$ 1.71 / \mathrm{lb}$. On average, the price differential between the PYO and prepicked fruit was $\$ 0.49 / \mathrm{lb}$ $(\$ 1.08 / \mathrm{kg})$.

The growers who cooperated in the consumer survey were not specifically asked how they set the prices for their PYO and prepicked berries. However when these price spreads were presented, some growers offered that they set the price spread based on the additional costs that they thought they incurred by selling the fruit at the roadside stand. Another grower said that he set his prepick price based on the price charged at the local grocery store. It is interesting to note that $89 \%$ of the customers who were surveyed at Location 1 purchased prepick strawberries. It was also obvious that most of the cooperators were not aware of the prices that the other growers charged for their fruit, possibly due to the physi- cal distance between the operations. Not surprisingly some of the growers indicated that they were going to rethink their prices for the next season when they saw the price data.

Since prices and yields can vary drastically, the projected net revenues were calculated for various combinations of direct market prices and marketable yields (Table 4). Direct market prices ranged from a low of $\$ 0.65 / \mathrm{lb}$ for PYO strawberries and $\$ 1.20 / \mathrm{lb}$ for prepicked strawberries to a high of $\$ 0.95$ and $\$ 1.50 / \mathrm{lb}$ for PYO and prepicked fruit, respectively. Yield estimates ranged from a low of 8,000 $\mathrm{lb} /$ acre $\left(8,966.6 \mathrm{~kg} \cdot \mathrm{ha}^{-1}\right)$ to a high of $24,000 \mathrm{lb} /$ acre $\left(26,899.8 \mathrm{~kg} \cdot \mathrm{ha}^{-1}\right)$.

It was estimated that growers would not receive a positive net return at any of the price combinations used in this analysis if they only achieve a yield of $8,000 \mathrm{lb} /$ acre using the plasticulture production system. Given a marketable yield of 12,000 lb/acre, growers would only receive a positive return if the PYO price was equal to or greater than $\$ 0.85 / \mathrm{lb}$ and the prepick price was $\$ 1.40 / \mathrm{lb}$ or higher. Positive net revenues were also projected for all of the price combinations if yields of 16,$000 ; 20,000$; or $24,000 \mathrm{lb} /$ acre $(17,933.2 ; 22,416.4$; or $26,899.8$ $\mathrm{kg} \cdot \mathrm{ha}^{-1}$ ) were attained.

BreakeVen yields. It is also important for strawberry growers to determine their breakeven yields, or the minimum volume of fruit that they must sell to cover their projected production, harvest, and market costs. Selling less fruit than the breakeven yield will result in a deficit financial position while selling more than the breakeven yield will generate enough revenues to cover the estimated expenses. Therefore the breakeven yields were calculated for each combination of

Table 4. Estimated net revenues per acre for strawberries grown in North Carolina using the plasticulture production system for varying pick-your-own and preprick prices and marketable yields.

\begin{tabular}{|c|c|c|c|c|c|c|}
\hline \multirow{2}{*}{$\begin{array}{l}\text { Pick-your-own } \\
\text { prices } \\
(\$ / 1 b)^{y} \\
\end{array}$} & \multirow{2}{*}{$\begin{array}{c}\text { Prepick } \\
\text { prices } \\
(\$ / 1 b)\end{array}$} & \multicolumn{5}{|c|}{ Marketable yield (lb/acre) } \\
\hline & & $\begin{array}{c}8,000 \\
(\$ / \text { acre })^{x}\end{array}$ & $\begin{array}{c}12,000 \\
\text { (\$/acre) }\end{array}$ & $\begin{array}{c}16,000 \\
(\$ / \text { acre })\end{array}$ & $\begin{array}{c}20,000 \\
\text { (\$/acre) }\end{array}$ & $\begin{array}{c}24,000 \\
\text { (\$/acre) }\end{array}$ \\
\hline 0.65 & 1.20 & $-5,077$ & $-2,193$ & 691 & 3,576 & 6,460 \\
\hline 0.70 & 1.25 & $-4,677$ & $-1,593$ & 1,491 & 4,576 & 7,660 \\
\hline 0.75 & 1.30 & $-4,277$ & -993 & 2,291 & 5,576 & 8,860 \\
\hline 0.80 & 1.35 & $-3,877$ & -393 & 3,091 & 6,576 & 10,060 \\
\hline 0.85 & 1.40 & $-3,477$ & 207 & 3,891 & 7,576 & 11,260 \\
\hline 0.90 & 1.45 & $-3,077$ & 807 & 4,691 & 8,576 & 12,460 \\
\hline 0.95 & 1.50 & $-2,677$ & 1,407 & 5,491 & 9,576 & 13,660 \\
\hline
\end{tabular}

${ }^{\mathrm{z}} 1.0 \mathrm{lb} / \mathrm{acre}=1.12 \mathrm{~kg} \cdot \mathrm{ha}^{-1}$.

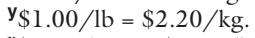

$\mathrm{x} \$ 1.00 /$ acre $=\$ 2.47 / \mathrm{ha}$. 
Table 5. Estimated breakeven strawberry yields per acre that must be sold to cover production, harvest and marketing costs for various combinations of pickyour-own and prepick prices assuming two-thirds of the yield was sold at a pickyour-own operation and one-third was sold at a fruit stand.

\begin{tabular}{|c|c|c|}
\hline $\begin{array}{l}\text { Pick-your-own } \\
\text { Strawberry } \\
\text { price } \\
(\$ / 1 \mathrm{~b})^{\mathrm{z}} \\
\end{array}$ & $\begin{array}{c}\text { Prepick } \\
\text { strawberry } \\
\text { price } \\
(\$ / 1 b) \\
\end{array}$ & $\begin{array}{c}\text { Breakeven } \\
\text { yield } \\
(\text { lb } / \text { acre })^{y}\end{array}$ \\
\hline 0.65 & 1.20 & 15,041 \\
\hline 0.70 & 1.25 & 14,066 \\
\hline 0.75 & 1.30 & 13,209 \\
\hline 0.80 & 1.35 & 12,451 \\
\hline 0.85 & 1.40 & 11,775 \\
\hline 0.90 & 1.45 & 11,169 \\
\hline 0.95 & 1.50 & 10,622 \\
\hline
\end{tabular}

${ }^{2} \$ 1.00 / \mathrm{lb}=\$ 2.20 / \mathrm{kg}$.

y $1.0 \mathrm{lb} /$ acre $=1.12 \mathrm{~kg} \cdot \mathrm{ha}^{-1}$

Table 6. The total number of pounds per acre and the estimated number of customers that must buy strawberries at directmarket operations to achieve the breakeven yields for the prices listed in Table 5 assuming pick-your-customers buy an average of $11.6 \mathrm{lb}(5.26 \mathrm{~kg})$ per visit and prepick customers buy an average of $7.1 \mathrm{lb}(3.22 \mathrm{~kg})$ per visit.

\begin{tabular}{|c|c|c|c|c|c|}
\hline \multicolumn{3}{|c|}{ Required sales volume to break even } & \multicolumn{3}{|c|}{ Number of customers to break even } \\
\hline $\begin{array}{l}\text { Break-even } \\
\text { yields } \\
(\text { lb/acre })^{z} \\
\end{array}$ & $\begin{array}{c}\text { Pick-your-own } \\
\text { sales } \\
\text { (lb/acre) } \\
\end{array}$ & $\begin{array}{c}\text { Prepicked } \\
\text { sales } \\
(1 \mathrm{~b} / \text { acre }) \\
\end{array}$ & $\begin{array}{c}\text { Pick-your-own } \\
\text { sales } \\
(\text { no./acre) })^{y} \\
\end{array}$ & $\begin{array}{c}\text { Prepicked } \\
\text { sales } \\
\text { (no./acre) }\end{array}$ & $\begin{array}{c}\text { Total } \\
\text { sales } \\
\text { (no./acre) } \\
\end{array}$ \\
\hline 15,041 & 10,027 & 5,014 & 865 & 707 & 1,572 \\
\hline 14,066 & 9,377 & 4,689 & 809 & 661 & 1,470 \\
\hline 13,209 & 8,806 & 4,403 & 760 & 621 & 1,381 \\
\hline 11,169 & 7,446 & 3,723 & 642 & 524 & 1,166 \\
\hline 10,622 & 7,081 & 3,541 & 611 & 499 & 1,110 \\
\hline
\end{tabular}

${ }^{\mathrm{z}} 1 \mathrm{lb} / \mathrm{acre}=1.12 \mathrm{~kg} \cdot \mathrm{ha}^{-1}$

${ }^{y} 1$ person $/$ acre $=2.5$ people $/$ ha

direct market prices used in this study. This breakeven analysis also assumed that two-thirds of the marketable yield was sold through the PYO operation and one-third was sold as prepicked berries at the fruit stand.

Obviously the lower the prices charged at each direct market outlet the larger the volume of fruit that must be sold to cover the estimated costs. For example, a PYO price of $\$ 0.65 /$ $\mathrm{lb}$ combined with a price of $\$ 1.20 / \mathrm{lb}$ for prepick berries means that growers would have to sell a minimum of $15,041 \mathrm{lb}$ of fruit per acre $(16,585.3$ $\left.\mathrm{kg} \cdot \mathrm{ha}^{-1}\right)$ to cover the projected expenses (Table 5). However, if a grower can receive $\$ 0.95$ and $\$ 1.50 / 1 b$ for the PYO and prepicked fruit, respectively, he would only have to sell $10,622 \mathrm{lb}$ of berries per acre $\left(11,905.4 \mathrm{~kg} \cdot \mathrm{ha}^{-1}\right)$ to breakeven.

MaRKet ANALYsis. A shortcoming of this analysis is that a market was assumed to exist and be accessible. That is, it was assumed that a sufficient number of consumers from the local marketing area would patronize the direct market outlets to make straw- berry production a viable option. If this situation does not exist, actual costs increase as the volume of unsold fruit rises because the money spent to produce, harvest and market unsold berries will not generate any revenue to flow back into the business. Therefore an analysis was performed for each price combination to give growers a rough idea of the number of customer sales that would have to be generated to cover total costs.

Two basic assumptions had to be made to calculate these estimates. First, two-thirds of the strawberries were again sold through PYO operations and one-third was sold as prepicked berries at a fruit stand. Second, PYO customers bought an average of 11.6 $\mathrm{lb}$ of strawberries per visit and prepick consumers purchased an average of 7.1 $\mathrm{lb}$. These were the average volumes of fruit purchased by customers at the eight direct markets in 1999.

The estimated volume of strawberries that must be sold through each direct market outlet and the associated number of customers that are needed to buy strawberries at these outlets are shown in Table 6. Given a PYO price of $\$ 0.65 / \mathrm{lb}$ and a prepick price of $\$ 1.20 / \mathrm{lb}$, it was estimated that 865 customers would have to buy 10,027 $\mathrm{lb} /$ acre $\left(11,238.5 \mathrm{~kg} \cdot \mathrm{ha}^{-1}\right)$ of berries at the PYO operation and 707 customers must buy $5,014 \mathrm{lb} /$ acre $(5,619.8$ $\left.\mathrm{kg} \cdot \mathrm{ha}^{-1}\right)$ at the fruit stand for the grower to sell a breakeven volume of 15,041 $\mathrm{lb} / \mathrm{acre}$. If the grower charged a PYO price of $\$ 0.95 / \mathrm{lb}$ and a prepick price of $\$ 1.50 / \mathrm{lb}$, the number of customers needed to sell the breakeven volume of 10,622 lb/acre decreases considerably. In this case 611 customers would have to buy $7,081 \mathrm{lb} /$ acre $(7,936.6$ $\mathrm{kg} \cdot \mathrm{ha}^{-1}$ ) at the PYO operation and 499 consumers must purchase 3,541 $\mathrm{lb} /$ acre $\left(3,968.8 \mathrm{~kg} \cdot \mathrm{ha}^{-1}\right)$ at the fruit stand to sell the breakeven volume. So based strictly on the conditions set forward in this study and depending on the actual price combination charged for the strawberries, a grower must attract between 1,110 and 1,572 customers per acre $(2,742.8$ and $3,884.4$ customers/ha) to breakeven.

Customer Profiles. It is obvious then that marketing is a critical element 
Table 7. Demographic information for the customers surveyed in 1999 at eight North Carolina direct-market strawberry operations where customers could either pick their fruit at the pick-your-own operation or buy prepick berries at the fruit stand.

\begin{tabular}{|c|c|c|c|}
\hline Parameter & $\begin{array}{c}\text { All } \\
\text { customers } \\
(\%)\end{array}$ & $\begin{array}{c}\text { Pick-your-own } \\
\text { customers } \\
(\%)\end{array}$ & $\begin{array}{c}\text { Fruit stand } \\
\text { customers } \\
(\%)\end{array}$ \\
\hline \multicolumn{4}{|l|}{ Age (years) } \\
\hline$<18$ & 0.6 & 0.6 & 0.3 \\
\hline $18-24$ & 2.5 & 3.3 & 1.9 \\
\hline $25-44$ & 34.5 & 43.1 & 25.2 \\
\hline $45-54$ & 18.3 & 15.2 & 21.8 \\
\hline $55-64$ & 16.9 & 14.3 & 19.7 \\
\hline$\geq 65$ & 27.2 & 23.5 & 31.1 \\
\hline Average & 51.7 & 49.2 & 54.3 \\
\hline \multicolumn{4}{|l|}{ Household income $(\$)$} \\
\hline$<15,000$ & 7.8 & 9.1 & 6.5 \\
\hline $15,000-29,999$ & 16.8 & 14.7 & 18.9 \\
\hline $30,000-44,999$ & 21.5 & 23.8 & 19.3 \\
\hline $45,000-59,999$ & 15.2 & 15.0 & 15.2 \\
\hline $60,000-74,999$ & 17.3 & 18.9 & 15.4 \\
\hline$\geq 75,000$ & 21.4 & 18.5 & 24.7 \\
\hline \multicolumn{4}{|l|}{ Adults working $\geq 40 \mathrm{~h}$ per week } \\
\hline None & 29.6 & 27.1 & 32.4 \\
\hline 1 & 40.0 & 43.9 & 36.0 \\
\hline 2 & 25.6 & 24.3 & 26.7 \\
\hline $3-4$ & 4.1 & 3.8 & 4.3 \\
\hline$>4$ & 0.7 & 0.9 & 0.6 \\
\hline \multicolumn{4}{|l|}{ Distance traveled $\left(\right.$ miles $\left.^{\mathrm{z}}\right)$} \\
\hline $0-4.9$ & 21.3 & 20.4 & 22.6 \\
\hline $5-9.9$ & 33.3 & 35.6 & 30.9 \\
\hline $10-19.9$ & 27.9 & 28.8 & 27.0 \\
\hline $20-49.9$ & 12.9 & 12.1 & 13.3 \\
\hline$\geq 50$ & 4.6 & 3.1 & 6.2 \\
\hline \multicolumn{4}{|l|}{ Average } \\
\hline Including customers traveling $\geq 50$ & 19.7 & 17.5 & 23.5 \\
\hline Excluding customers traveling $\geq 50$ & 9.9 & 9.8 & 9.9 \\
\hline
\end{tabular}

${ }^{2} 1.0$ mile $=1.61 \mathrm{~km}$.

to the success of a direct market operation. Knowing who their customers are, why they buy strawberries, and why they select a specific outlet can help direct market operators generate the volume of traffic needed to break even and be successful. The consumer survey revealed that the typical PYO customer was between 25 and 44 years old, had an annual household income between $\$ 30,000$ and $\$ 44,999$, and at least one family member worked $40 \mathrm{~h}$ or more per week (Table 7). The second largest age group was 65 years old or older and the second most frequent income category was $\$ 60,000$ to $\$ 74,999 /$ year. However a significant number of customers earned $\$ 75,000 /$ year or more and ranked a close third. Excluding those who drove over 50 miles $(80.5 \mathrm{~km})$, the average number of miles customers drove to the operation was 9.8 miles $(15.77 \mathrm{~km})$, with $35.6 \%$ driving between 5 and 9.9 miles $(8.1$ and $15.93 \mathrm{~km})$ and $28.8 \%$ driving between 10 and 19.9 miles (16.1 and $32.03 \mathrm{~km})$.

The normal prepick customer was also between 25 and 44 years old and had a household income of $\$ 75,000 /$ year or more with at least one family member working $40 \mathrm{~h}$ or more per week. The second largest age group was 65 years old or older and the second most frequent income category was $\$ 30,000$ to $\$ 44,999 /$ year. The average age was 54.3 years old and over $32 \%$ of the customers were retirees. Again excluding those who drove over 50 miles, the average mileage prepick customers drove to the fruit stand was 9.9 miles, with $30.9 \%$ driving between 5 and 9.9 miles and $27.0 \%$ driving between 10 and 19.9 miles.

Females shopping alone made up the largest population of shoppers followed by shopping parties composed of males shopping alone, male and female couples, and females with children (Table 8). Most females and males that were alone bought berries at the fruit stand while the majority of the shopping parties that included children frequented PYO operations. In fact, females who came with children comprised the second largest group that picked their own strawberries.

Overall, a third of the respondents had never previously visited the direct market operation where they were interviewed while two-thirds were repeat customers, having either picked and/or purchased strawberries at the same farm before (Table 9). PYO

Table 8. Composition of the shopping parties interviewed at eight North Carolina direct-market operations in 1999 where the customers could either pick fruit at the pick-your-own operation or buy berries at the fruit stand.

\begin{tabular}{lccc}
\hline $\begin{array}{l}\text { Members in the } \\
\text { shopping party }\end{array}$ & $\begin{array}{c}\text { All } \\
\text { customers } \\
(\%)\end{array}$ & $\begin{array}{c}\text { Pick-your-own } \\
\text { customers } \\
(\%)\end{array}$ & $\begin{array}{c}\text { Fruit stand } \\
\text { customers } \\
\text { (\%) }\end{array}$ \\
\hline Adult female & 30.8 & 13.1 & 17.6 \\
Adult male & 19.4 & 6.9 & 8.2 \\
Adult female and male & 17.2 & 10.3 & 9.5 \\
Adult female with one or more children & 13.1 & 4.3 & 2.8 \\
Two or more adult females & 8.0 & 2.7 & 3.7 \\
Adult female and male with children & 3.3 & 1.3 & 0.6 \\
Two or more adult males & 3.2 & 2.3 & 1.9 \\
Two or more adult females with children & 2.9 & 0.8 & 0.6 \\
Adult male with children & 1.7 & 0.3 & 0.9 \\
Two or more adult males with children & 0.4 & 50.2 & 0.1 \\
Total & 100.0 & 49.8 \\
\hline
\end{tabular}


Table 9. Picking history of the customers interviewed at eight North Carolina direct-market strawberry operations in 1999 where the customers could either pick fruit at the pick-your-own operation or buy berries at the fruit stand.

\begin{tabular}{|c|c|c|c|}
\hline Question & $\begin{array}{c}\text { All } \\
\text { customers } \\
(\%) \\
\end{array}$ & $\begin{array}{c}\text { Pick-your-own } \\
\text { customers } \\
(\%)\end{array}$ & $\begin{array}{c}\text { Prepick } \\
\text { customers } \\
(\%)\end{array}$ \\
\hline \multicolumn{4}{|l|}{ Is this your first visit to this farm? } \\
\hline No (repeat customers) & 67.0 & 60.9 & 74.3 \\
\hline \multicolumn{4}{|c|}{ Did you buy or pick strawberries on this farm earlier this year? } \\
\hline Yes (at least the second visit this season) & 45.2 & 42.4 & 47.8 \\
\hline \multicolumn{4}{|l|}{$\begin{array}{l}\text { Have you visited any other direct-market } \\
\text { operation this year to buy or pick strawberries? }\end{array}$} \\
\hline Yes & 11.5 & 11.3 & 11.5 \\
\hline No & 88.5 & 88.7 & 88.5 \\
\hline
\end{tabular}

Table 10. Intended use of the strawberries purchased by the customers interviewed at eight North Carolina direct-market strawberry operations in 1999.

\begin{tabular}{lccc}
\hline $\begin{array}{l}\text { Intended } \\
\text { use }^{\mathrm{z}}\end{array}$ & $\begin{array}{c}\text { All } \\
\text { customers } \\
(\%)\end{array}$ & $\begin{array}{c}\text { Pick-your-own } \\
\text { customers } \\
(\%)\end{array}$ & $\begin{array}{c}\text { Fruit stand } \\
\text { customers } \\
(\%)\end{array}$ \\
\hline Consume as fresh fruit & 88.3 & 88.6 & 88.4 \\
Freeze the fruit & 26.5 & 35.4 & 17.3 \\
Process as jam or jelly & 10.5 & 14.2 & 6.5 \\
Other & 9.2 & 9.9 & 8.7 \\
\hline
\end{tabular}

Table 11. The quantity of strawberries purchased by the customers interviewed at eight North Carolina direct-market strawberry operations in 1999.

\begin{tabular}{lcc}
\hline & $\begin{array}{c}\text { Pick-your-own customers } \\
\text { bought this } \\
\text { quantity of fruit } \\
\text { Qu) }\end{array}$ & $\begin{array}{c}\text { Fruit stand customers who } \\
\text { bought this } \\
\text { quantity of fruit } \\
\text { (\%) }\end{array}$ \\
\hline $1-5^{\mathrm{z}}$ & 24.2 & 53.1 \\
$6-10$ & 36.1 & 29.8 \\
$11-15$ & 20.7 & 9.7 \\
$16-20$ & 7.7 & 4.1 \\
$>20$ & 11.3 & 3.3 \\
Average & 11.6 & 7.1 \\
\hline
\end{tabular}

${ }^{\mathrm{z}} 1.0 \mathrm{lb}=0.45 \mathrm{~kg}$

Table 12. Consumer's ranking of the most important factors that influenced their decision to purchase strawberries at eight North Carolina direct-market operations in 1999.

\begin{tabular}{lccc}
\hline Factor & $\begin{array}{c}\text { All } \\
\text { customers } \\
\text { (rank) }\end{array}$ & $\begin{array}{c}\text { Pick-your-own } \\
\text { customers } \\
\text { (rank) }\end{array}$ & $\begin{array}{c}\text { Fruit stand } \\
\text { customers } \\
\text { (rank) }\end{array}$ \\
\hline Freshness & 1 & 1 & 1 \\
Taste & 2 & 2 & 2 \\
Firmness & 3 & 3 & 3 \\
Fruit color & 4 & 4 & 4 \\
Fruit size & 5 & 5 & 5 \\
Price & 6 & 6 & 6 \\
\hline
\end{tabular}

operations accounted for the highest percentage of new customers, 39.1\%, and the prepick fruit stands had the largest percentage of repeat customers, $74.3 \%$. Slightly more than $42 \%$ of the repeat PYO customers had picked strawberries earlier in the season at the same operation compared to $47.8 \%$ of the prepick buyers who had purchased berries at the same fruit stand. Just over $11 \%$ of the consumers had either picked or bought strawberries at other direct market operations earlier in the year.

Purchase patterns. Not surprisingly, the vast majority of the customers planned to consume the strawberries fresh (Table 10). Freezing the berries was the second most popular use and processing the fruit for jam or jelly was the third most prevalent use. A larger percentage of the PYO customers intended to process the strawberries compared to the prepicked customers. More than 35\% of the PYO customers were going to freeze the strawberries versus $17.3 \%$ of the prepick customers, and $14.2 \%$ of the PYO consumers were going to use the fruit to make jam or jelly versus $6.5 \%$ of the prepick customers.

As was previously discussed, PYO customers picked an average of 11.6 $\mathrm{lb}$ and prepick customers bought an average of $7.1 \mathrm{lb}$ of fruit (Table 11). Exit interviews disclosed that $36.1 \%$ of the PYO customers picked 6 to $10 \mathrm{lb}$ $(2.7$ to $4.5 \mathrm{~kg}$ ) of berries while $53.1 \%$ of the prepick customers bought between $\mathrm{l}$ and $5 \mathrm{lb}(0.5$ to $2.3 \mathrm{~kg})$ at the fruit stand. It is also significant to note that $39.7 \%$ of the PYO consumers picked $11 \mathrm{lb}(5.0 \mathrm{~kg})$ or more of strawberries compared to $17.1 \%$ of the prepicked consumers who purchased the same amount of berries at the fruit stand.

When asked to rank how important six factors were relative to their decision to purchase strawberries, both sets of customers ranked these factors in the same order (Table 12). Freshness was the most important factor while taste was ranked second, fruit firmness was third, fruit color was fourth, fruit size was fifth and price was ranked last. It was not surprising, therefore, that good fruit quality was the major reason consumers said that they decided to pick more strawberries than they had anticipated (Table 13) and poor quality was the primary cause for their decision to pick less fruit than expected (Table 14). Consumers who discovered that the strawberries were easier to pick than they had expected ranked the ease of picking as having a positive impact on 
Table 13. Reasons customers picked more strawberries than they expected to pick at eight North Carolina pick-your-own strawberry operations in 1999.

\begin{tabular}{lrr}
\hline & \multicolumn{2}{c}{ Customers } \\
\cline { 2 - 3 } Reason & (no.) & (\%) \\
\hline Good fruit quality & 112 & 57.7 \\
Easier to pick than expected & 49 & 25.3 \\
Good fruit size & 15 & 7.8 \\
Low prices & 9 & 4.6 \\
Other & 9 & 4.6 \\
\hline
\end{tabular}

Table 14. Reasons customers picked fewer strawberries than they expected to pick at eight North Carolina pick-your-own strawberry operations in 1999.

\begin{tabular}{lrr} 
& \multicolumn{2}{c}{ Customers } \\
\cline { 2 - 3 } Reason & (no.) & (\%) \\
\hline Poor fruit quality & 23 & 31.1 \\
Fields were too picked over-not enough fruit & 13 & 17.6 \\
Too hot to pick & 5 & 6.8 \\
Small fruit size & 3 & 4.0 \\
Too hard to pick strawberries & 3 & 4.0 \\
Fields were too muddy & 1 & 1.4 \\
High prices & 0 & 0.0 \\
Other & 28 & 35.1 \\
\hline
\end{tabular}

Table 15. Amounts customers spent for strawberries at eight North Carolina pick-your-own strawberry operations in 1999.

\begin{tabular}{lccc}
\hline $\begin{array}{c}\text { Amount } \\
\text { spent }(\$)\end{array}$ & $\begin{array}{c}\text { All } \\
\text { customers } \\
(\%)\end{array}$ & $\begin{array}{c}\text { Pick-your-own } \\
\text { customers } \\
(\%)\end{array}$ & $\begin{array}{c}\text { Fruit stand } \\
\text { customers } \\
(\%)\end{array}$ \\
\hline 0 & 0.1 & 0.0 & 0.3 \\
$1-10$ & 70.5 & 66.7 & 75.1 \\
$11-20$ & 20.7 & 24.6 & 16.2 \\
$21-30$ & 5.7 & 6.1 & 5.1 \\
$31-50$ & 1.9 & 1.8 & 2.1 \\
$>50$ & 1.1 & 0.8 & 1.2 \\
Average & 10.20 & 10.30 & 9.40 \\
\hline
\end{tabular}

how much fruit they eventually picked while picked over fields or the lack of strawberries had the second largest negative impact on consumer picking decisions.

While price did not have a major impact on the amount of strawberries the consumers purchased, statistical analysis indicated that price had a major impact on their decision to either pick their fruit or buy the berries at the fruit stand. That is, customers who thought that the price of the prepick berries was too high relative to the price of the PYO berries, decided to pick their fruit rather than buying the strawberries at the fruit stand. Conversely, if consumers felt that there was relatively little difference between the two prices they opted to buy their berries at the fruit stand rather than picking the fruit.

Overall, the average amount of money consumers spent for strawberries was $\$ 10.20$, with PYO customers spending an average of $\$ 10.30$ and prepick customers spending an average of $\$ 9.40$ (Table 15). Two-thirds of the PYO customers spent between $\$ 1$ and \$10 while one-third spent \$11 or more compared to about three-fourths of the prepick customers who spent less than $\$ 10$ and almost one-fourth who spend more than $\$ 11$.

Advertising. When asked what prompted their visit to the farm where they were interviewed, $<23 \%$ of all the respondents said that advertising influenced their shopping decision while $>77 \%$ indicated that their decision was not influenced by any type of advertisement. Of the 379 customers who were influenced by a specific advertisement, 208 , or $56.8 \%$ of these respondents, said that the advertisement that prompted their visit to the farm was posted on either a sign or billboard (Table 16). Newspaper advertisements had the second largest impact with a $22.4 \%$ response rate while direct mailers were a distant third with $5.7 \%$. Newspaper inserts, radio commercials, and commercial television advertisements each recorded a response rate of $<2.0 \%$. Only two people referred to an advertisement on cable television and two individu-

Table 16. Consumer response rates to different types of advertisements promoting eight North Carolina direct-market strawberry operations in 1999.

\begin{tabular}{lrr}
$\begin{array}{l}\text { Type } \\
\text { of } \\
\text { advertisement }\end{array}$ & \multicolumn{1}{c}{$\begin{array}{c}\text { Customers who } \\
\text { responded to } \\
\text { an advertisement }\end{array}$} \\
\hline Signs or billboards & (no.) & $\mathbf{( \% )}$ \\
Newspaper advertisement & 208 & 56.8 \\
Direct mail brochure, flyer or postcard & 82 & 22.4 \\
Newspaper insert & 21 & 5.7 \\
Radio commercial & 7 & 1.9 \\
Commercial television advertisement & 5 & 1.4 \\
Cable television advertisement & 3 & 0.8 \\
Internet Web page & 2 & 0.6 \\
Yellow Pages advertisement & 2 & 0.6 \\
Association or NCDA\&CS pick-your-own directory & 0 & 0.0 \\
Other & 0 & 0.0 \\
\hline
\end{tabular}

${ }^{\mathrm{Z}}$ North Carolina Department of Agriculture and Consumer Services. 
Table 17. Key Information contained in the advertisements that attracted customers to one of eight North Carolina direct-market strawberry operations in 1999.

\begin{tabular}{lccc}
\hline $\begin{array}{l}\text { Key information } \\
\text { in the } \\
\text { advertisement }\end{array}$ & $\begin{array}{c}\text { All } \\
\text { customers } \\
(\%)\end{array}$ & $\begin{array}{c}\text { Pick-your-own } \\
\text { customers } \\
(\%)\end{array}$ & $\begin{array}{c}\text { Fruit stand } \\
\text { customers } \\
(\%)\end{array}$ \\
\hline Fresh strawberries & 62.4 & 62.3 & 63.6 \\
Farm location & 33.0 & 34.3 & 29.0 \\
Strawberry prices/sale & 0.6 & 0.4 & 0.9 \\
Coupons & 0.6 & 0.0 & 1.9 \\
Hours of operation & 0.3 & 0.0 & 0.9 \\
Other & 3.1 & 3.0 & 3.7 \\
\hline
\end{tabular}

als located the direct market operation via the Internet. Yellow page ads and the PYO directory published by the strawberry association and North Carolina Department of Agriculture and Consumer Services (NCDACS) were not mentioned by anyone. However, there is subsequent evidence that more consumers are now using the Internet to locate direct market operations. During the 6-week strawberry season in 2003 , there were $>8,000$ visits to NCDACS's new Internet farm market directory, "NCFarmFresh.com" (NCDACS, 2003).

When asked what information in the advertisement attracted them to the strawberry operation, $62.4 \%$ of the customers said that the phrase "fresh strawberries" influenced their decision and $33 \%$ said that information about the location of the farm affected their decision (Table 17). Publicizing information about strawberry prices and the hours of operation or offering redeemable coupons collectively only persuaded $1.5 \%$ of these respondents to visit a direct market outlet.

Since a large portion of the customers did not respond to an advertisement, it could also help growers promote their market operations if they know why these individuals decided to buy berries at their farm. Customers whose visit was not motivated by advertising were presented a list of possible reasons for selecting a direct marketing outlet and asked to select the primary reason that influenced their decision to stop at the operation. First-time PYO customers said that the convenient location of the farm was the primary reason that influenced their decision about where to pick strawberries and a referral from a family member of friend was second (Table 18). Convenient location was also the most significant factor that influenced repeat PYO customers' decision to return to the same operation, more than doubling the percentage of buyers who listed fruit quality. Furthermore, convenient location was the major reason that influenced prepick customers to visit the fruit stands. More than 36\% of the first-time consumers and over $39 \%$ of the repeat customers listed this factor as the main reason for selecting a fruit stand (Table 19). In addition, $19 \%$ of the first-time customers just happened to drive by the fruit stand and decided to stop while $18.3 \%$ selected the fruit stand based on a referral from

Table 18. The primary reasons first-time customers decided to pick berries at one of eight North Carolina pick-your-own strawberry operations in 1999 compared to the repeat customers interviewed at the same operations. ${ }^{\mathrm{z}}$

\begin{tabular}{|c|c|c|c|c|}
\hline \multirow{2}{*}{$\begin{array}{l}\text { Reason for } \\
\text { shopping }\end{array}$} & \multicolumn{2}{|c|}{ First-time customers } & \multicolumn{2}{|c|}{ Repeat customers } \\
\hline & Rank & $(\%)$ & Rank & $(\%)$ \\
\hline Convenient location & 1 & 34.0 & 1 & 45.6 \\
\hline Personal referred & 2 & 28.7 & 3 & 15.1 \\
\hline Family outing & 4 & 2.7 & 6 & 2.2 \\
\hline Farm experience & 5 & 2.1 & 5 & 2.4 \\
\hline Drove by and decided to stop & 6 & 1.8 & 4 & 3.8 \\
\hline Exercise & --- & 0.0 & --- & 0.0 \\
\hline Buy a large volume of strawberries & --- & 0.0 & 8 & 0.3 \\
\hline Other & NA & 19.5 & NA & 13.4 \\
\hline
\end{tabular}

${ }^{\mathrm{z}}$ This question was only asked to those customers who said that their decision to visit the direct-market operation was not prompted by an advertisement.

Table 19. The primary reasons first-time prepick customers decided to buy strawberry at one of eight North Carolina fruit stands in 1999 compared to the repeat customers interviewed at the same operations. ${ }^{\mathrm{z}}$

\begin{tabular}{|c|c|c|c|c|}
\hline \multirow{2}{*}{$\begin{array}{l}\text { Reason for } \\
\text { shopping }\end{array}$} & \multicolumn{2}{|c|}{ First-time customers } & \multicolumn{2}{|c|}{ Repeat customers } \\
\hline & Rank & $(\%)$ & Rank & $(\%)$ \\
\hline Convenient location & 1 & 36.6 & 1 & 39.3 \\
\hline Drove by and decided to stop & 2 & 19.0 & 5 & 8.4 \\
\hline Personal referred & 3 & 18.3 & 3 & 11.4 \\
\hline Strawberry quality & 4 & 10.5 & 2 & 19.2 \\
\hline Farm Experience & 5 & 2.6 & 4 & 9.0 \\
\hline Strawberry variety/selection & 6 & 0.7 & 6 & 1.2 \\
\hline Family outing & 6 & 0.7 & 7 & 0.6 \\
\hline Low prices & --- & 0.0 & 8 & 0.4 \\
\hline Exercise & --- & 0.0 & --- & 0.0 \\
\hline Buy a large volume of strawberries & --- & 0.0 & 9 & 0.2 \\
\hline Other & NA & 11.6 & NA & 10.3 \\
\hline
\end{tabular}

${ }^{\mathrm{z}}$ This question was only asked to those customers who said that their decision to visit the direct-market operation was not prompted by an advertisement. 
Table 20. The daily percentage of pick-your-own and fruit stand customers who completed a consumer survey at one of eight North Carolina direct-market operations in 1999.

\begin{tabular}{lcc}
\hline Day & $\begin{array}{c}\text { Pick-your-own } \\
\text { customers } \\
(\%)\end{array}$ & $\begin{array}{c}\text { Fruit stand } \\
\text { customers } \\
(\%)\end{array}$ \\
\hline Monday & 10.3 & 11.0 \\
Tuesday & 13.3 & 11.1 \\
Wednesday & 14.5 & 13.3 \\
Thursday & 13.5 & 22.1 \\
Friday & 24.5 & 25.7 \\
Saturday & 24.1 & 16.8 \\
\hline
\end{tabular}

${ }^{\mathrm{z}}$ Surveys were not conducted on Sundays.

Table 21. The amount of time pick-your-own and fruit stand customers spent at one of eight North Carolina direct-market strawberry operations in 1999.

\begin{tabular}{lcc}
\hline $\begin{array}{l}\text { Time spent } \\
\text { at the } \\
\text { direct market }\end{array}$ & $\begin{array}{c}\text { Pick-your-own } \\
\text { customers } \\
(\%)\end{array}$ & $\begin{array}{c}\text { Fruit stand } \\
\text { customers } \\
(\%)\end{array}$ \\
\hline$<15 \mathrm{~min}$ & 33.8 & 90.2 \\
$15-30 \mathrm{~min}$ & 18.3 & 6.6 \\
$31-45 \mathrm{~min}$ & 16.1 & 1.1 \\
$46-60 \mathrm{~min}$ & 19.1 & 0.6 \\
$>60 \mathrm{~min}$ & 12.7 & 1.5 \\
\hline
\end{tabular}

Table 22. The average dollar expenditures pick-your-own and fruit stand customers spent at one of eight North Carolina direct-market strawberry operations in 1999 compared to the amount of time they spent picking berries or buying fruit at the fruit stand.

\begin{tabular}{lcc}
\hline $\begin{array}{l}\text { Time spent } \\
\text { at the } \\
\text { direct market }\end{array}$ & $\begin{array}{c}\text { Pick-your-own } \\
\text { customers } \\
\text { (\$/customer) }\end{array}$ & $\begin{array}{c}\text { Fruit stand } \\
\text { customers } \\
\text { (\$/customer) }\end{array}$ \\
\hline$<15 \mathrm{~min}$ & 7.52 & 9.78 \\
$15-30 \mathrm{~min}$ & 9.67 & 9.52 \\
$31-45 \mathrm{~min}$ & 8.53 & 13.07 \\
$46-60 \mathrm{~min}$ & 12.44 & 10.36 \\
$>60 \mathrm{~min}$ & 17.00 & 16.13 \\
\hline
\end{tabular}

family members or friends. The second most frequent factor for repeat prepick customers was the quality of the strawberries followed by referrals.

Peak traffic days. While determining the peak consumer traffic periods was not an objective of this study, the total number of completed surveys per day was directly related to the volume of customer traffic and gives some insight into the busiest days of operation. For PYO operations, Friday barely edged out Saturday as the busiest day of the week with $24.3 \%$ of the total respondents compared to $24.1 \%$, so in reality, there was no difference between these two days (Table 20). The shopping pattern for the prepick operations, on the other hand, followed the typical commercial supermarketshopping pattern for strawberries. That is, sales start slow on Monday and Tuesday, build up on Wednesday and Thursday, peak on Friday, and drop off on Saturday.

Over $90 \%$ of the customers who purchased prepick strawberries at the fruit stands completed their transactions within 15 min while $6.6 \%$ of the shoppers took between 15 to $30 \mathrm{~min}$ to make their purchases (Table 21). It is interesting to note that many of the customers who were recorded as staying longer than $30 \mathrm{~min}$ at the fruit stand initially started picking strawberries at the PYO operation. These individuals grew tired of picking and finished buying the volume of berries they wanted at the fruit stand where they completed the second part of the interview.

Predictably, the majority of the PYO customers stayed at the farm longer. While about one-third of the pickers took $<15$ min to pick their berries and checkout, slightly $>19 \%$ of the consumers needed between 46 and $60 \mathrm{~min}$ to complete their transactions and almost $13 \%$ stayed longer than an hour. Also not surprisingly, the PYO customers who picked longer typically spent more money (Table 22). The average amount PYO customers spent gradually increased from an average of $\$ 7.52$ for those who stayed less than $15 \mathrm{~min}$ to $\$ 17.00$ for those individuals who stayed longer than an hour. The only exception to this trend was the consumers who stayed between 31 and $45 \mathrm{~min}$ who spent an average of $\$ 8.53$ per customer.

\section{Conclusions}

The total annual harvest, marketing, and production costs for the plasticulture production system were estimated to be $\$ 13,540$ /acre with material inputs accounting for $49.8 \%$, or $\$ 6,750 /$ acre, of the total costs. Labor costs made up slightly over $38 \%$, or $\$ 5,180 /$ acre, of the total and the costs associated with owning and operating the equipment comprised almost $12 \%$, or $\$ 1,611 /$ acre.

Net revenue analysis revealed that growers would have to charge at least $\$ 0.85$ and $\$ 1.40 / \mathrm{lb}$ for PYO and prepicked fruit, respectively, and sell a minimum of $12,000 \mathrm{lb}$ of strawberries per acre to cover the estimated costs. Breakeven analysis also indicated that growers would have to sell a minimum of $15,041 \mathrm{lb} /$ acre at the lowest combination of direct market prices considered in this study and at least $10,622 \mathrm{lb} /$ acre at the highest prices to cover total expenses. It was further assumed that an average of $11.6 \mathrm{lb}$ of fruit would be sold to PYO customers and an average of $7.1 \mathrm{lb}$ would be sold to customers who visited the fruit stand. Under these assumptions, the breakeven yield of $15,04 \mathrm{ll} / \mathrm{b} /$ acre translated into a requirement to sell fruit to at least 1,572 customers per acre at the lowest combination of prices while a breakeven yield of $10,622 \mathrm{lb} /$ acre converted to a minimum of 1,110 customers per acre at the highest prices.

Middle age, middle-income customers living within 10 miles of the farm comprised the largest percentage of customers surveyed at the PYO operations. However customers with lower household incomes generally accounted for the largest average expenditures. Middle-age, high-income individuals who also live within ten miles of the fruit stand were the largest group of respondents at the prepick operations whereas customers with household incomes greater than 
$\$ 60,000 /$ year typically accounted for the greatest expenditures. The initial site selected for the direct market operation can have a long-term effect on the success, or failure, of the business. Therefore growers should locate as close to population areas that closely resemble the demographic characteristics of consumers identified in this study. Managers should also monitor the demographic changes within these market areas so they can adjust their operations to meet their customers' changing requirements.

Overall, convenient location was the major reason that customers decided to patronize a specific direct market outlet while a personal referral was second. Since word-of-mouth, or referrals by family members or friends, are so important in attracting new customers, growers who satisfy their customer's expectations in terms of fruit quality and service will have a comparative advantage in attracting new consumers. Satisfied customers give positive referrals if they are pleased with the product and service. Conversely, customers who have purchased poor quality fruit or received poor customer assistance normally share their negative experiences with an even greater number of people. Given that $67 \%$ of the patrons are repeat customers, growers could incorporate these individuals into their marketing strategy by actively encouraging their regular customers to tell their friends about the operation. For example, growers could provide brochures about the direct market operation for customers to give to their friends or discount incentives could be given to regular customers to bring in new customers.

Impulse buying was the second most important reason that affected first-time customers' decision to select a fruit stand. That is, customers happened to be driving by a fruit stand, found the operation attractive, and decided to stop. This high percent- age of impulse buyers reinforces the importance for direct market operators to select a convenient location for their business and to use good signage to attract customers. It also supports the notion that managers should be sensitive to how their operation is viewed by the public. Other research has shown that neat, clean direct market operations with ample parking, safe entries and exits off and onto the highway and attractive fruit displays help persuade customers to stop at these businesses.

Customers, whose shopping trip was prompted by an advertisement, said that the phrase fresh strawberries or the information about the farm location in the advertisement attracted them to the direct market operation. Managers should highlight this information in any print and radio advertisement and ensure that this information is clearly visible in their signage. Emphasizing the availability of fresh prepicked strawberries may also be beneficial because some potential customers may not realize that local strawberry producers also operate a fruit stand. While there is no guarantee that any form of advertisement will be effective, other consumer studies have found that retail managers who repeatedly focused their media ads on a simple, specific message, recorded higher response rates than those who did not.

Although Fridays and Saturdays are still the preferred shopping days, a large percentage also find other days convenient. Managers should assess individual market areas, determine when their customers prefer to shop and adjust their operating hours accordingly. Further inquiry into why average expenditures decreased if customers left the PYO operations between 31 and $45 \mathrm{~min}$, indicated that this is the approximate time frame where some consumers become hot and tired of picking berries. Growers may be able to negate this tendency by placing comfort stations where customers can sit down to rest and get a drink of water at strategic locations in the strawberry field. In other situations, the owner may be able to direct customers to the fruit stand where they can buy any additional berries that they may have intended to purchase.

The cost data can serve as a guide to assist individuals who are currently growing strawberries, those considering entering the direct market strawberry business, or professionals who are advising strawberry growers make more informed business management decisions. However as a final caveat, growers and professionals should remember that any budget is only a guide and is not a substitute for individuals calculating their own cost and estimating their own breakeven yields. Costs vary from one producer to another because of market conditions, labor supply, age and condition of the machinery and equipment, managerial skill, land costs and many other factors. Since every situation is different, it is highly recommended that each grower estimate their individual production, marketing, and harvest costs based on their own production techniques, price expectations, and local market situation.

\section{Literature cited}

North Carolina Department of Agriculture and Consumer Services. 2003. North Carolina Farm Fresh. 31 July 2003. <http: //www.NCFarmFresh.com>.

Safley, C.D., M.K. Wohlgenant, and R.E. Suter. 2002. Factors affecting consumer purchases of direct market strawberries. Agr. Resour. Econ. Rpt. 22. Dept. Agr. Resour. Econ., N.C. State Univ., Raleigh.

Safley, C.D., E.B. Poling, and O. Sydorovych. 2003. Estimated costs of producing, harvesting, and marketing strawberries in North Carolina. N.C. State Univ. N.C. Ext. Bul. Raleigh (in press). 